Article

\title{
Vehicle Crime, CPTED, and Offending under the Influence: A Qualitative Investigation of Offender Perceptions
}

\author{
Anthony Quinn \\ Department of Sociology, Social Policy and Criminology, Faculty of Economic, Social and Political Sciences, \\ University of Southampton, Southampton SO17 1BJ, UK; a.quinn@soton.ac.uk
}

Received: 14 January 2019; Accepted: 6 March 2019; Published: 9 March 2019

\begin{abstract}
Crime prevention through environmental design (CPTED) can impact upon where an offender decides to commit an offence. This is particularly the case for street-level acquisitive crime. There has been little coverage, within research on crime and offending, of how aspects of the built environment might be interpreted by a motivated offender who has a dependency on either illicit drugs, alcohol or both of these. This study draws on qualitative interviews with twenty individuals who have received criminal convictions for vehicle crime offences. Within these offender interviews, images, of repeatedly victimised areas, were examined in order to gauge in what capacity various locations were vulnerable to vehicle crime. Through this examination, pertinent points were made by participants about how and why the appeal of locations could differ for offenders who suffer from substance addiction and offenders who do not. The key findings of this research demonstrate that vehicle crime offenders who are not dependent on drugs or alcohol, may be more risk-averse than those who are. Moreover, both types of offender might become part of organised crime networks, but these findings make an initial suggestion that those who offend under the influence are more vulnerable to coercion by a criminal hierarchy.
\end{abstract}

Keywords: vehicle crime; CPTED; drugs and alcohol; offender-based research; qualitative research

\section{Introduction}

The importance of scrutinising situational cues in order to understand offending, particularly street-level acquisitive crime, is well-documented (see Brantingham and Brantingham 1978; Wortley 2001; Cornish and Clarke 2003; Wortley and Townsley 2017; Armitage 2018; Armitage et al. 2018). For domestic burglary offences, aspects of the built environment, such as vegetational cover, have signalled the attractiveness of a property to be burgled (Nee and Taylor 2000; Armitage and Monchuk 2017). The presence of other features, such as a 'wheelie bin' (recycling dustbin), can be perceived to facilitate acquisitive offences (Ekblom 2011; Garwood 2011). An example of a situational cue is a street sign that indicates 'private property'; this could deter some thieves but it could attract others because it conveys the presence of property that might be of value (Armitage 2017; Armitage and Monchuk 2017). With regards to vehicle offences, the cover of vegetation, one-way roads, and open space through which an offender(s) could escape were all reported by offenders to be aspects of the built environment that could influence decisions to offend or not (Quinn and Grove 2018). Each of these examples engages with the central tenets of situational crime prevention (Brantingham and Brantingham 1978, 1981; Clarke 1980; Cornish and Clarke 2003) that emanate from the rational choice perspective (Cornish and Clarke 1986, 2017; Felson 1994; Clarke and Felson 2004). These perspectives inform us that in situations where criminal opportunity can be perceived, and the reward outweighs the risk (Bentham 2012), a rational choice might be made to commit an offence (Cornish and Clarke 1986). For instance, if an individual notices that there 
is sufficient cover from identification when seeking to offend (see Nee and Taylor 2000; Armitage and Monchuk 2017; Quinn and Grove 2018), then they might be more likely to offend there based on their perceived likelihood of success and the unlikelihood of detection (Cornish and Clarke 1986, 2003, 2017; Cornish 1994).

Despite an understanding of the situational features that can inform offender decision-making, less is known about how the built environment is interpreted by an offender with impaired thoughts (see Cornish and Clarke 1986, 2017; Felson 1994; Clarke and Felson 2004). Rational thought could be affected if individuals are under the influence of illicit drugs and alcohol or dependent upon their consumption (see Holloway et al. 2004; Armitage et al. 2018). Some offenders commit shoplifting offences under the influence of drugs and alcohol or when they are experiencing withdrawal from them (Armitage et al. 2018). When it comes to the act of offending, substance dependence can influence perceptions of risk (Armitage et al. 2018). To refer to a risk calculation (Bentham 2012) within the rational choice perspective (Cornish and Clarke 1986, 2017; Felson 1994; Clarke and Felson 2004), impairment caused by drugs or alcohol could alter the level of risk that an offender is willing to take. For example, an offender who is under the influence might risk committing an offence without the presence of cover (see Nee and Taylor 2000; Armitage and Monchuk 2017), or they might feel less confident that it will diminish their risk of detection because of substance-induced paranoia (see Collison 1996), or they might be indifferent to its presence. For the present study, in order to probe an association between drug and alcohol dependency and offender perceptions of the potential to commit vehicle offences, there are two questions to answer:

1. Do offenders under the influence of drugs or alcohol seem to perceive opportunities and risks of committing vehicle crime differently to those whose offending is unrelated to drugs and alcohol?

2. If there are variations in how dependent offenders perceive opportunities and risks of committing vehicle crime, what do these relate to?

Like domestic burglary and shoplifting offences, vehicle offences fit within the classification of acquisitive crime because they involve the theft, or attempted theft, of property for profit (Everson and Pease 2001). Vehicle offences can be described as high-volume or low in harm (see Sherman et al. 2016). Another similar characteristic of vehicle offences is that their occurrence can be concentrated, for instance, where surveillance is poor, where vehicle security measures are not adopted or where offenders and dealers of stolen goods reside (Farrell et al. 1995). To give some insight into what vehicle offences entail, their prevalence and why a focus on this crime type is worthwhile, government legislation and statistics need to be documented. The Home Office (2018) states that vehicle offences include:

Aggravated Vehicle Taking-when a motor vehicle is stolen and driven dangerously.

Theft from a Motor Vehicle-when property is stolen from a motor vehicle.

Theft or Unauthorised Taking of a Motor Vehicle-when a motor vehicle is stolen.

Interfering with a Motor Vehicle-when a motor vehicle is interfered with or it is unclear if attempts were made to steal something from the vehicle or to steal the vehicle itself.

The recorded volume of vehicle offences decreased every year from March 2003 until March 2015 when it begun to increase each year (Office for National Statistics 2018). In 2018, there were more vehicle offences $(457,970)$ recorded than for the acquisitive offences of burglary $(432,267)$ and robbery $(79,117)$, and the Office for National Statistics (2018) suggests that this reflects a genuine increase in the volume of vehicles offences committed. Every year, theft from a motor vehicle (TFMV) has constituted more than half of recorded vehicle offences (Home Office 2016). Theft or unauthorised taking of a motor vehicle (TOMV) is the second most recorded, whilst aggravated vehicle taking and interfering with a motor vehicle represent only a small percentage of recorded vehicle offences (Home Office 2016). However, these statistics only give a representation of how many vehicle crime offences occur on a macro-level 
(Brantingham and Brantingham 1981); to engage with situational features of offending on a micro-level (Brantingham and Brantingham 1981), a meso-level (Brantingham and Brantingham 1981) understanding of vehicle offences should be offered. Put differently, reasons why there are clusters of victims need to be understood so potentially vulnerable locations can be identified, and their characteristics examined (Brantingham and Brantingham 1981).

Several research studies provide a meso-level examination of vehicle offences (see Copes 1999; Johnson et al. 2006, 2009; Lockwood 2012; Suresh and Tewksbury 2012; Levy 2014). Vehicle offences have been found to cluster in space and time (Johnson et al. 2006, 2009); however, TFMV tends to be more closely clustered than TOMV (Johnson et al. 2006). These clusters usually appear in built-up areas due to the presence of more motor vehicles and a greater number of prying offenders (Farrell et al. 1995; Copes 1999). In particular, long residential streets are likely to be a favoured choice of target (Copes 1999; Quinn and Grove 2018). Levy (2014) found that vehicle crime clusters are likely to emerge in parking lots, especially those close to shopping centres. These findings signify that certain contexts have been identified as more susceptible to vehicle crime victimisation than others. Research has been conducted on where vehicle crime might occur and upon features of the built environment that are likely to impact upon decisions to offend, such as: lighting (Painter and Farrington 2001; Clarke 2010; Levy 2014), CCTV (Armitage 2002; Welsh and Farrington 2008), and warning signposts (Bowers and Johnson 2003; National Audit Office 2007). For crime more generally, Jacobs (1993) asserts that 'eyes upon the street' or onlookers are an essential measure for reducing the likelihood of offences being committed. What seems to be lacking is a micro-level (Brantingham and Brantingham 1981) investigation into how all of these factors might be interpreted by an individual with a desire to commit vehicle crime; in addition, if and how these interpretations could differ under the influence of drugs and alcohol. If it is not known which contexts are likely to be vulnerable and why this is the case, then it is unlikely that appropriate crime prevention resources will be deployed.

The original contribution of this study is to begin an exploration of how opportunities for vehicle offences are interpreted by those dependent on drugs or alcohol and those who are not, so that by 'thinking thief' (Ekblom 1997), the built environment can be designed to reduce the likelihood of victimisation. This method of direct engagement with individuals who have committed offences has been termed 'offender-based research' (see Copes and Vieraitis 2009; Gill and Goldstraw-White 2010; Bernasco 2011; Armitage et al. 2018). To compare how drug and alcohol consumption might shape offender decision-making between consumers and non-consumers, the perceptions of both groups are required. This study explores the role that CPTED plays in the commission of vehicle crime by examining the perspectives of individuals who have received criminal convictions for these offences. It is not only the immediate environment where offending occurs that warrants coverage (Brantingham and Brantingham 1981) but wider mechanisms (Pawson and Tilley 1997), too. It could transpire that certain situations are neither conducive nor prohibitive towards offending but rather that there are structural considerations which trigger offending opportunity to be sought after (Pawson and Tilley 1997). As recognised by Bennett and Holloway (2010, p. 589), "there are many different mechanisms operating which explain the connection between drug use and crime" and it should not be assumed that drug use causes crime by itself (Bennett and Holloway 2010). Decisions to offend can be driven by several mechanisms and not just one (Pawson and Tilley 1997; Bennett and Holloway 2010).

Mechanisms (Pawson and Tilley 1997) associated with vehicle offences include: drug use (Holloway et al. 2004), unemployment (Light et al. 1993), impulsivity (Cherbonneau and Copes 2006), peer pressure (Light et al. 1993), and membership in a criminal network (Brown 2016; Kleemans and Soudijn 2017). These factors could shape where vehicle offences occur and the regularity of them, for instance, if there are high concentrations of unemployed individuals who are willing to commit vehicle offences despite the risks that are involved, such as being caught by the police or 'jumped on' by an onlooker (see Light et al. 1993, p. 29). Vehicle offences are likely to occur close to where offenders live or spend a significant amount of time (Wiles and Costello 2000). Kleemans and Soudijn (2017) propose that 
it is more likely to be somewhat desperate acquisitive offenders that take advantage of nearby low-level criminal opportunities than criminals involved in organised networks. Criminals involved in an organised network might be highly motivated and take greater care in planning (Kleemans and Soudijn 2017), but that does not mean they will not seek to benefit from the proceeds of street-level crime and those who take advantage of the built environment for criminal gain-for example, "economic compulsive crime might include shoplifting to raise money for drugs" (Bennett and Holloway 2010, p. 589) and transaction with a criminal network to exchange stolen property thereafter (Bennett and Holloway 2010). The wider context might tell us as much about why offending occurs in a particular place as the immediate (built) environment (Pawson and Tilley 1997). This is a consideration for the current study because it demonstrates that as important as the built environment might be for explaining why offending occurs (see Armitage 2017), it is not the only factor (Pawson and Tilley 1997) that merits exploration.

\section{Results}

Each participant was given several minutes to view eight images of repeatedly victimised locations. Interviewees were then asked to share their thoughts on why vehicle offences might or might not occur at these locations based on what they could perceive within the images. Participants declared how their impressions were shaped by a stage in their lives when they had committed offences and themes related to addiction were promptly mentioned by those whose offending had been linked to drugs or alcohol. Those who disclosed a greater number of convictions for vehicle offences seemed more at ease identifying features that would facilitate offending (see Ekblom 2011; Garwood 2011) than those who had only one or a couple of convictions. This could support the findings of Cherbonneau and Copes (2006) and Copes and Cherbonneau (2006) which reveal that with experience committing vehicle offences, offender perceptions of opportunity improve. Some whose offending was unrelated to drugs or alcohol explained how their offending choices would be different from this group (usually indicating that they would be savvier). Participants who disclosed that they had been addicted to, or under the influence of drugs or alcohol, at the time of offending have the letters 'DA' after their name. The number before some of the qualitative accounts allows the reader to pair the item under discussion with the labelled images in Appendix A.

\subsection{Risk versus Reward Calculations}

For Dwayne, who mentioned that drugs and alcohol did not play a role in his offending, location 1 appeared to be too risky to offend within because of the CCTV surveillance that was seemingly present. As a result, he would not even enter this location. However, this would not necessarily deter an offender who was under the influence of drugs:

1. Dwayne: you see, they'd risk that coz they'd be under the influence of drugs, so they'd go in there. But if that was me then I wouldn't go into that one [car park at location 1]. I'd just leave that and say: 'it's not worth my while' unless it was ... it's just the camera mate.

When probed as to how he was aware of this, Dwayne stated that he knew a few individuals who were influenced by drugs or alcohol, but he was quick to distance himself from them and their offending choices. There is a possibility Dwayne was hypothesising about what other offenders would do; however, the following accounts from those who expressed dependency match this description about lesser regard for risk. Moreover, the most pressing point about the description of Dwayne is that it shows how members of this sample promptly made assertions about their offending style. The sober offender tends to allude to risk as a prohibiting factor, whereas this was less the case for the offender who is dependent. Risk versus reward calculations (Cornish and Clarke 1986, 2017; Felson 1994; Clarke and Felson 2004) might differ between those whose offending is related to drugs and alcohol and those for whom it played no part. Those who are dependent or under the influence at the time of offending might be regarded as more willing to take chances when faced with forms of security; those who are not would be more likely to be deterred. In this scenario, the threshold for risk to outweigh 
potential reward (Cornish and Clarke 1986, 2017; Felson 1994; Clarke and Felson 2004) is met sooner for the offender who is not a regular consumer of drugs or alcohol. Whether the camera(s) under discussion would actually lead to detection cannot be tested, but what is clear is that for some, it could act a suitable deterrent. To validate the account of Dwayne, a description of the same location by a dependent offender is offered:

2. Interviewer: do you think someone could do it [commit a vehicle offence] here [location 1]? Lawrence (DA): yeah, quite easily. Interviewer: go on ... Lawrence (DA): anyone can do it anywhere. It depends how desperate you are innit? And that's it. Interviewer: yeah? but like here you mentioned that Lawrence (DA): yeah it is pretty safe but it's still ... y'know what I mean? If, say for instance a drug addict were gonna do it and they needed to get a fix, they ain't gonna care. They'd still do it no matter how blatant it would be.

The account of Lawrence supports that substance-related offending would be more likely to take place. It suggests why, and this relates to the offender being in want of immediate resources "to get a fix" (Lawrence) of drugs or alcohol. As the last part of this account indicates, the prospect of implementing effective deterrence for all types of offender is unlikely because some place higher worth on satisfying an addiction than on the likelihood of detection (Armitage 2018; Armitage et al. 2018). For burglary and shoplifting offences as well (Armitage 2018; Armitage et al. 2018), addiction is likely to increase propensity to offend. In these studies, and the current study, an offender sample supported the observation that "typically, many individual crimes are viewed as impulsive, gain-now / pay-later affairs" (Ekblom 2017, p. 36). Dwayne and Lawrence described how features of the built environment take on greater significance for a more calculated sober offender, whereas for the drug or alcohol consumer, assessment can make way for impulse and determination.

\subsection{The Presence of Opportunity}

Closely linked to addiction, risk versus reward calculations, and whether to frequent an area is an obvious presence of offending opportunity (see Cornish and Clarke 1986, 2017; Felson 1994; Clarke and Felson 2004). Opportunity in itself is a pressing point of analysis because it conveys the effectiveness and ineffectiveness of features of the built environment to deter offending; this variance depends on the sobriety and collectedness of the offender. The accounts which follow explain this further. The first two show the inevitability of an offence occurring if the offender encounters a motor vehicle or property to steal; the third and fourth exhibit that an offence might still occur if a sober offender encounters the same opportunity; however, it will usually be preceded by close inspection.

Don (DA): The biggest thing that's gonna make someone steal from a car is them seeing something in that car because some people are that desperate that they don't care what time of day it is, who's about or whatever. They're that desperate because they need it [drugs/alcohol] they'll ... if they see something in that car, they'll break into it.

Craig (DA): I worked for him, so the keys were in the office.

Interviewer: yeah? and so you just thought

Craig (DA): I thought I'd take the van until I get paid but obviously I was drunk like. I was summin' like six or seven or eight times over the limit when they breathalysed me so obviously . . but I'd hit a few things as well so ... I wrote the van off.

Paul: you go and check it out yourself. You don't... you don't just go there and do the crime there and then.

Sacha: you'll go there [the] day before if it's like... if it's a ... if it's a little car, you'll go there before, and you'll have a quick look around. If it's a big car for big money, you'll look around a week ... you'll see ... you know you'll do set timings, set routines, which way the guy... like if you've got a target then that's that car ... you'll see how he'll go, where he'll go, his timing, what he'll do ... if you're takin' it. 
In the accounts of Don (DA) and Craig (DA), opportunity to steal is immediately taken advantage of. This provides further example of the impulsivity (Ekblom 2017) of the vehicle crime offender when encountering opportunity under the influence of drugs or alcohol. There is no mention of a possibility of detection; the offending decision is bounded (see Simon 1990; Copes and Vieraitis 2009; Cornish and Clarke 2017) in so far as there is only consideration of whether the theft can be committed 'there and then' (without allusion to consequences). For some offenders, if opportunity presents itself, then it will be acted upon, which somewhat challenges the notion of Cornish and Clarke (2003, p. 72) that offenders "are not clockwork toys who will offend at all costs".

This is in contrast to offenders without a dependence on drugs or alcohol, who reported that if they discovered opportunity, then they would endeavour to assess the possible repercussions of offending. The narrative of Sacha chimes with the routine activity theory (see Clarke and Felson 2004) in that a decision to offend involves an assessment of when an offender might encounter a suitable target in the absence of a capable guardian. As Sacha went on to disclose, 'to have a quick look around' involved inspecting aspects of the built environment that could link him to the scene of the crime, like the presence of CCTV or features that could hinder a getaway like narrow or busy roads. The insight that Paul offered reinforces the point that a prolonged offender assessment was required rather than an instant, and possibly incriminating, decision; as was the case with Don (DA) and Craig (DA).

\subsection{Dependence and Perceptions of Repeat Victimisation}

Within repeat victimisation studies, 'the flag hypothesis' (Farrell et al. 1995) describes situations whereby an offender returns to where they have successfully offended to exploit similar opportunities. These resultant offences are 'near repeats' (Morgan 2001). An initial offence can educate an offender, which makes a return to that area more likely (Everson and Pease 2001). In the case of dependent offenders, perceptions of how easily similar set-ups could be victimised seemed more optimistic than those who were not regular consumers of drugs or alcohol. This is not to suggest that dependent offenders did not act rationally but rather that their actions were more impulsive and less measured than they might have been if they had not been suffering from addiction. Here, the recollections of a TOMV and a TFVM are given, and they allude to opportunities that were flagged up (Farrell et al. 1995) in close proximity to initial targets.

Mark (DA): We've got our 5 grand [five thousand pounds]. My reaction's gonna be like that's a big party that ... that's my drugs, drink, whatever

Interviewer: yeah,

Mark (DA): you then say 'shit, we're out of money' ... well then, the next day, we knew there was a nice car sitting next door and we think: 'wow, that's an easy picking', I'll clear the house and take the car.

Lawrence (DA): they did leave them open and they'd be money in there so like if I was on that estate I'd go to all them ones first and it used to pay off a lot. Y'know what I mean?

Interviewer: yeah. So, when you were doing that was there any need to go anywhere else?

Lawrence (DA): not really, no. Once I got enough money to get my gear [drugs], I'd go.

These two accounts are distinct from the narrative of Darren who expressed no involvement in drugs or alcohol. As mentioned in the previous sections, this type of offender appears less willing to take risks even if obvious opportunity presents itself:

Darren: we never had an exact number coz you can never go to the same areas. It'd always

Interviewer: because?

Darren: because say you'd stolen from there, everyone in that area'd know 
The decisions of Mark (DA) and Lawrence (DA) to return to, or continually offend in, the same area, regardless of the composition of the built environment, supports the work of Copes and Cherbonneau (2006). They found that "opportunities appear to materialize out of thin air; and the easier these opportunities seem, in terms of effort and risk; the more they engender an irresistible desire to take full advantage of them" (Copes and Cherbonneau 2006, p. 920). When Mark (DA) and Lawrence (DA) had offended successfully, their next action was not to cease offending but to take advantage of similar victims and to find the means to satisfy their addiction; thus, repeat victimisation occurred (Farrell et al. 1995). The boldness of Mark's (DA) and Lawrence's (DA) account in comparison to the caution of Darren suggests that offending under the influence, or with drugs and alcohol in mind, might enhance the apparent easiness of an opportunity (Copes and Cherbonneau 2006). For Darren, an offender who was not substance-dependent, a return to commit an act of repeat or near repeat victimisation (Farrell et al. 1995; Morgan 2001) would not be considered. Rather than this being because of improvements to the built environment, such as the installation of CCTV cameras (Armitage 2002; Welsh and Farrington 2008) in the aftermath of an offence, a reluctance to return was caused by a perception that those who frequent that area would be alert to the presence of a vehicle crime offender. This endorses the concept of 'eyes upon the street' (Jacobs 1993) and the safety that can be instilled by the presence of bystanders. For the reasons explored, acquisitive offending that is linked to drugs and alcohol (Mark and Lawrence) appears more likely to reoccur in close proximity than the offending of a more composed criminal (Darren).

\subsection{Converged Perceptions of the Built Environment}

Thus far, comparisons between the offending decisions of regular drug and alcohol consumers and non-consumers have focused on discernible differences in perceptions. This section demonstrates that there were also instances when the decision-making of these two types of offender appeared to converge. When this was the case, it tended to relate to how the built environment, where targets are situated, can provide signals about possibilities for successful offending. The following extracts reflect these common perceptions:

3. Aaron: [about location 4] probably a bit safer coz it ... it looks like a better area. Interviewer: right, ok. Aaron: bigger houses ... people would probably be a bit more ... I can imagine people being a bit more nosey or ... I see a caravan there. There might be old people that are in all the time. Ermm ... I'd probably say it's a bit safer.

4. Don (DA): I don't know whether they'd be anything really in these cars [in location 2] because it doesn't look like a very affluent area but then again students sometimes leave laptops and things like that. It could be student accommodation because it looks like flats ermm ... so I'd say that would be the easiest there if there was anything in view in the cars.

In support of the research of Armitage (2017) and Armitage and Monchuk (2017) that probed the effect private signs and seemingly affluent housing might have on offender perceptions, there was a consensus that the preferred location to commit theft was in less affluent areas. Features that helped this sample of offenders to identify an affluent area included: bigger houses (Aaron), Neighbourhood Watch signs (Dwayne), retirement housing (Darryl), signs reminding owners to take valuable belongings out of vehicles (Don), and large driveways (Ali). These findings link to the concept of collective efficacy (Ekblom 2005; Sampson 2006) and the notion that ownership can be imposed upon an area by maintaining order or giving off that impression. In a similar fashion to ideas of 'Broken Windows' (Wilson and Kelling 1982), and 'Defensible Space' (Newman 1973), pro-social design and its maintenance can convey to a potential offender that offending is likely to be challenged.

However, if there were expensive vehicles, or work vehicles, parked on the street or on an open driveway, then the affluent area would become appealing: 
5. Sacha: [about location 3] You see cars like this, you won't take. You need something like Range Rovers; they're good money-Range Rovers.

6. Phil: [about location 4] work vans ... a lot of guys who've turned [a]round and predominantly steal tools... which is a major thing and also, vans are, or used to be, quite the commodity because vans are very easy to strip down. You can buy a van quite cheaply, have an engine fitted from a stolen vehicle, and they're not as hard as you think

In these instances, the promise of potential reward serves to outweigh what risk might have been imposed (Cornish and Clarke 1986, 2017; Felson 1994; Clarke and Felson 2004) by the appearance of the built environment. Pro-social design could only go so far to deter an offender; if an opportunity clearly presented itself, then it would likely be seized upon, which further supports the work of Copes and Cherbonneau (2006) and compulsion to seize upon obvious opportunity. Nevertheless, whether under the influence of drugs and alcohol or not, offenders preferred to target locations where it seemed they were less likely to be challenged and where vehicles were less likely to have been secured (locked in the case of TFMV and fitted with additional security, such as steering locks, in the case of TOMV). These accounts indicate that offenders believed they were more likely to encounter these scenarios in less affluent areas.

\subsection{The Wider Context for Drug and Alcohol Related Vehicle Crime}

In this final section, it is necessary to investigate the wider context that influenced the commission of vehicle offences, beyond features of the immediate built environment. This provides an appreciation of the wider mechanisms (Pawson and Tilley 1997) that can influence target selection and the regularity with which substance-related offending can occur. It suggests that offenders who exploit victims can also be the subject of coercion by a criminal hierarchy. This primarily derives from the risk that the addicted offender is expected to take, when stealing vehicles, for the benefit of a criminal organisation. The account below provides insight into this process; Alex stated that his offending had been related to the transportation and selling of stolen vehicles, more so than the stealing of them:

Alex: I'd say below me I've got the little bag-rats, for want of a phrase, that I used to speak to and say: "look, I need this car, in this colour".

Interviewer: can you just like describe to me what is involved in that description?

Alex: ok a bag-rat is somebody who's a heavy drug-taker

Interviewer: right.

Alex: who'll do next to anything for drugs. So, what we used to do is we used to give them a little black box ermm ... and then we'd just say: "keep that black box on you. Keep your phone on ya". We'd phone up and say, for example: "we need a blue whatever ... a blue Transit van; yeah? Go and get me a blue Transit van on a 2016 plate. Phone me when you've done it!"

Whereas for some offenders, vehicle offences were related to acting on impulse (Copes and Cherbonneau 2006), for others, the theft of a vehicle was part of an organised process that required certain types of vehicle to be stolen in particular areas. This was found to be the case by Clarke and Brown (2003), who documented how there are certain types of vehicle that are stolen to order, often because it can be lucrative to transport them across international borders and to sell them. Offenders who suffered from addiction were described as ideal candidates to commit thefts because they were regarded as being more desperate than the average offender (see Bennett and Holloway 2010) and would be less likely to question the risk, primarily of being apprehended by the police, of offending (see the first findings section). The terminology used, such as 'bag-rat' (Alex), reflects the negative regard within which these offenders can be held by those within a criminal hierarchy; they are simply a means to an end (see CriminologyTV 2017); similar coercion of drug- and 
alcohol-dependent individuals has been found for organised fraud where 'smack-heads' are tasked with money laundering for the benefit of more sophisticated criminals (CriminologyTV 2017).

After the motor vehicle had been moved to a safe place and had its identity changed (see Clarke and Brown 2003), the risk of identification by law enforcement was deemed to be lowered, and this was the point when criminals (like Alex) further up the supply chain became involved in this criminal process. Pro-social design might not be the instigator of whether a vehicle offence occurs but rather the directions of criminal peers who offer payments if the requested vehicle is, at the appropriate time, left in a safe place (Clarke and Brown 2003) for processing by a criminal network. Instructions from other criminals, and a perceived efficiency of the 'black box' (Alex), provide the offender with the impetus to commit an offence, and it is up to the dependent offender to choose their target. It is at this point that pro-social design becomes relevant because the dependent offender ideally requires a vehicle that is situated in a location that will not result in their apprehension. However, as expressed in the first Findings section, the dependent offender is more likely to offend despite perceived risks of apprehension so enhanced methods of crime prevention are required against this type of offender.

\section{Discussion}

This analysis explained possible differences in the way that drug- and alcohol-dependent offenders make offending decisions compared to offenders who are not dependent. The former group provided accounts about offending that were less risk-averse because of their desperation to sell the proceeds of theft in order to satisfy an addiction. When asked to scrutinise a set of images depicting victimised locations, offenders who had not been addicted tended to peruse the built environment more extensively. An important distinction was the presence of opportunity; offenders who were not suffering from addiction conveyed that they would inspect an area closely before offending as opposed to acting upon impulse (see Ekblom 2017). Increased propensity to take advantage of opportunity evoked an increased likelihood of drug- and alcohol-dependent offenders targeting near repeat victims (see Farrell et al. 1995; Morgan 2001). This less-measured approach of substance-dependent offenders is aligned with the findings of Armitage et al. (2018, p. 132) that provide insight into why and how shop-theft can occur as a result of drug "desperation' and altered decision-making". This study offered reasons why some vehicle crime offenders will be unlikely to pass up an obvious opportunity to acquire a vehicle or property within it (see Copes and Cherbonneau 2006). On the other hand, the offenders interviewed, especially the drug- and alcohol-dependent, suggested that they set out to discover offending opportunity as opposed to just encountering it by chance, as found by Copes and Cherbonneau (2006).

There are also similarities in the way that these two types of vehicle crime offender react to situational cues to offend (see Brantingham and Brantingham 1978; Wortley 2001; Cornish and Clarke 2003; Wortley and Townsley 2017). There was a consensus that less affluent areas were more suitable for offending within because the built environment in affluent areas was more likely to include: well-positioned CCTV, heightened security against criminals, and 'eyes upon the street' (Jacobs 1993). References were made to areas where students reside as being more fruitful for offenders, whereas locations where older people live were not favourable because this demographic were interpreted to be inquisitive towards their surroundings. Participants stated that they could usually guess the demographics of the area based on the appearance of the built environment around where motor vehicles were situated. The exception to this preference for less affluent areas was when a high-value vehicle needed to be stolen to order (see Clarke and Brown 2003). In this case, vehicle security was perceived to be less of a deterrence because offenders disclosed going equipped with technology, that they had been supplied with, to gain access to vehicles. With instructions to steal a particular vehicle, addicted offenders might prefer to target a less protected area, given the choice, but the interview data did not suggest that this would be a pressing concern.

In order to reduce the likelihood of vehicle offences being committed, particularly by those addicted to drugs and alcohol, there are three issues in particular that demand attention. The first 
involves security measures that can deter offenders by making it more difficult to steal motor vehicles. Some of these include: Effectively positioned CCTV, use of signal blockers that prevent car key signals being trapped (see Solon Security 2018), and the parking of vehicles behind obstacles such as bollards or gates so they cannot be accessed by prying offenders. Secondly, some who have committed vehicle offences, or who are likely to, could benefit from tailored support that addresses drug and alcohol addiction. Such guidance could explain the unsustainability of committing (vehicle) offences to satisfy addiction and the seriousness of supplying stolen goods to coercive organised crime networks that offset much risk of detection to the offender. This support of dependent offenders could take place in prison and probation facilities or as part of an out-of-court disposal; a suitable example is offered by Butler et al. (2011).

Thirdly, particularly for the case of TOMV, criminal networks who profit from the commission of vehicle offences should be infiltrated. The incorporation of pro-social design and heightened security in victimised areas may go some way to reducing the volume of vehicle offences, but if criminal organisations offer vulnerable offenders with the objective and the means to commit acquisitive crime, then this enticement must be addressed. As well as implementing CPTED and focused policing (see Clarke 2010), it is imperative to continue, or even to improve, the provision of resources for policing collaborations between The National Crime Agency and local forces (The National Crime Agency 2011). This is so that the trade of stolen vehicle and property can be shut down and those who facilitate the commission of vehicle crime can be brought to justice. Crime should be designed out beyond the micro-place (Brantingham and Brantingham 1981) where theft is committed.

This small-scale study highlighted key themes, but within future research into the commission of vehicle offences, it would be insightful to incorporate novel methods of qualitative engagement, such as the use of body-worn cameras by participants (see Armitage et al. 2018). This would allow for enhanced descriptions of how acquisitive offenders interpret the built environment, and it would provide an offender sample with a greater freedom to explore and commentate (Nee et al. 2015; Armitage et al. 2018). It would be unethical for offenders to participate whilst intoxicated but, as was the case in this research, participants could be probed when reflecting upon a time when they offended under the influence of drugs or alcohol. Methods of experimental psychology (see Nee and Ward 2015; Nee et al. 2015) could allow for analysis of the speed with which offenders can perceive a criminal opportunity and what type of targets they prioritise (see Nee and Taylor 2000; Armitage et al. 2018). This could lead to improved security measures being deployed in vulnerable locations and could be scrutinised during rehabilitative programmes with offenders. Offenders could be routinely instructed that just because they perceive seemingly rewarding opportunity (see Copes and Cherbonneau 2006), this does not mean that it is worthwhile to take advantage of it. The current study has provided a foundation upon which the perceptions of offenders can inform how drug and alcohol addiction can lead certain contexts to appear more attractive for offending than they otherwise would be to a non-dependent offender.

\section{Materials and Methods}

\subsection{Recruitment}

The qualitative data for this study were obtained from offenders who were recruited with the assistance of the Derbyshire Leicestershire Nottinghamshire and Rutland Community Rehabilitation Company. This organisation provides probation services to counties within the East Midlands (UK); due to size of this area, participants were recruited only from Leicestershire. After being given information sheets that explained the purpose and value of their input to the research, some probation practitioners referred suitable interview participants by searching their caseloads for vehicle crime convictions. The sampling method therefore constituted a 'convenience sample' (Bryman 2016). This method of selection could have led to overly positive responses as a result of probation practitioners only contacting service users who would not reflect badly on their organisation; 
this was countered by conducting interviews in private and by informing participants that all interview data would remain confidential and anonymous. Nineteen males and 1 female were recruited, and all participants were between the ages of 18 and 47. Collectively, this sample had received over 200 criminal convictions for vehicle offences, and information about their profiles can be found in Table A1 in Appendix A. No further participants were sought after it was felt that a point of theoretical saturation (Flick 2006) had been reached and it was felt there was sufficient information power (Malterud et al. 2015) to critically assess mechanisms (Pawson and Tilley 1997) with a role to play in vehicle crime repeat victimisation. Moreover, obtaining the accounts of individuals processed by the criminal justice system is a complex and time-consuming procedure (Elffers 2011), especially without offering financial incentives to participants (Curtis 2011). Nevertheless, similar small samples of offenders have produced credible and informative examination of criminal decision-making (see Cromwell et al. 1991; Copes et al. 2012; Nee et al. 2015; Armitage 2018; Armitage et al. 2018).

\subsection{The Qualitative Interview}

After participants had provided written consent to be interviewed with an audio recorder and for resultant data to be held securely for ten years after research completion, they were invited to take part in an interview within probation facilities that would not last longer than one hour. Semi-structured qualitative interviews were appropriate because they allow for a focused elaboration upon pre-set topics that relate to offending (see Pawson 1996). Participants were ordered to discuss only offences that they had been reprimanded for because of an ethical duty to report undetected offences to the appropriate authorities. There were two parts to the interview; the second half was based around themes relating to repeat victimisation (see Farrell et al. 1995; Everson and Pease 2001; Morgan 2001), such as reasons for target selection. The first half required participants to examine images that depicted repeatedly victimised locations in the years preceding the research interviews. These locations were pinpointed after quantitative analysis of police-recorded crime data which involved utilising Near Repeat Calculator Version 1.3 (see Ratcliffe 2009) and GIS mapping software. The eight images showed four different locations (two different angles of each location) and were displayed to participants on a computer tablet so that they could zoom in and out and closely inspect the built environment. This research method has been employed by Nee and Taylor (2000), Armitage (2018) and Armitage et al. (2018), whilst Nee (2011) advocates the use of 'proxy' observational methods, such as images of real places, because they can assist the offender in contextualising offending decisions. Participants were asked if they believed that these areas were secure or vulnerable to vehicle offences and to explain their perceptions. The images referred to can be viewed in Appendix A; the number labels allow them to be matched to the quotation that refers to that feature. Contemplation about drugs, alcohol, and dependence at the time of offending was unprompted and emerged through explanations of how participants would have perceived the depicted locations around the time of their apprehension. The interview data were coded thematically (Bryman 2016) based on the topics consistently referred to.

\subsection{Methodological Limitations}

Qualitative interviews with offenders were undertaken because they could be overseen by staff within a criminal justice facility (see Zetinigg and Gaderer 2011). A more ethnographic method from the outset might have been considered 'dangerous' (Nee and Taylor 2000) for the researcher due to a lack of familiarity with the offender sample. A form of participant observation (see Cromwell et al. 1991; Nee and Taylor 2000; Armitage et al. 2018) with a similar population should be a next step to validate and to gain further details about how vehicle crime opportunity is perceived. This follow-up sample has been described as an 'intensive dozen' (Humphreys 1970, p. 36; see Cherbonneau and Copes 2006). Offenders might be described as an unreliable source of data because of a reluctance to share successful methods of offending (Leclerc 2017). This was partially overcome through recruiting within a probation environment where the ethos is geared towards rehabilitation and turning away from offending lifestyles. As a result, participants may have been less apprehensive about sharing details of a discontinued activity. 
Offenders might not be able to recall all of their impressions at the time of offending (Elffers 2011), especially when under the influence of drugs or alcohol; however, this reservation could be directed towards much retrospective qualitative enquiry; the use of visuals helped to counter this because they can be memory-enhancing for an offender sample (Nee 2011). Imagery and verbal discussion can be formed into an effective method of triangulation whereby the combined strengths of the two methods negate accepted limitations (Nee 2011). Twenty offenders from one county might not be representative of all offenders who commit vehicle offences; yet at the same time, the obtained sample had received over 200 vehicle crime convictions. Offenders on probation with convictions for vehicle offences constitute a hard-to-reach sample (Elffers 2011), so the importance of representativeness must partially give way to rich qualitative accounts (Curtis 2011). It might have been beneficial to interview more females for comparison; however, the researcher had to accept the offerings of probation practitioners and was unable to recruit more purposively (see Curtis 2011; Bryman 2016).

\section{Conclusions}

Based on the presented findings, it is tentatively stated that there are differences in the way that drug- and alcohol-dependent offenders commit vehicle offences compared to those whose offending is unrelated to drugs or alcohol. This signifies how situational decisions to offend can differ dependent on the needs of the offender; given that a great deal of acquisitive offences is linked to drug and alcohol consumption, this preliminary analysis requires consolidation. This article proposed that vehicle crime offenders are not a homogeneous group and that features of the built environment which might deter some will not necessarily dissuade those seeking to satisfy an addiction. Offenders under the influence might choose to take greater risks, conduct less extensive inspection before offending, and be more likely to commit acts of near repeat victimisation. Convergence between the offending decisions of addicted and non-addicted individuals concerned a preference to offend in less affluent areas because of a smaller chance of encountering surveillance or security measures. Pro-social design takes on appeal if it instils doubt within offenders and conveys hostility towards offending. Those interviewed provided examples of how offending by drug- or alcohol-dependent offenders can be instigated by requests from organised crime groups. If this is widespread, there is a twofold challenge for government policy. Firstly, because CPTED seems to only go so far to protect potential victims, particularly from those who are drug- or alcohol-dependent, possible targets should be made aware of the need to heighten security. Secondly, improved policing would be required to infiltrate the organised crime networks that provide a demand for stolen vehicles and exploit the vulnerability of offenders who are dependent on drugs and alcohol.

Funding: This research received no external funding and was undertaken as part of a fully funded PhD at Loughborough University (UK).

Acknowledgments: The author would like to thank Loughborough University, the Derbyshire Leicestershire Nottinghamshire and Rutland Community Rehabilitation Company and Leicestershire Police for facilitating this research into vehicle offences.

Conflicts of Interest: The authors declare no conflict of interest. 


\section{Appendix A}

Table A1. Participant Demographics.

\begin{tabular}{|c|c|c|c|c|c|c|c|c|c|}
\hline Number & Age & $\begin{array}{l}\text { Number of Vehicle } \\
\text { Crime Convictions }\end{array}$ & TFMV & TOMV & AVT & IWMV & $\begin{array}{l}\text { Stealing for } \\
\text { Financial Gain }\end{array}$ & $\begin{array}{c}\text { Involved in } \\
\text { Organised Crime }\end{array}$ & $\begin{array}{l}\text { Drug or Alcohol Issues (at } \\
\text { the Time of Offending) }\end{array}$ \\
\hline 1 & 38 & 37 & $x$ & $x$ & $x$ & & $X$ & & $x$ \\
\hline 2 & 35 & 13 & $X$ & & & $X$ & $X$ & & \\
\hline 3 & 29 & 2 & $x$ & $x$ & $X$ & $x$ & $x$ & $x$ & $x$ \\
\hline 4 & 20 & 3 & $x$ & & $x$ & & & & \\
\hline 5 & 37 & 1 & & $x$ & & & & & $x$ \\
\hline 6 & 33 & 30 & $x$ & $x$ & $x$ & $X$ & $x$ & & \\
\hline 7 & 33 & 1 & & $x$ & & & & & $X$ \\
\hline 8 & 38 & 1 & $x$ & & & & $X$ & & $X$ \\
\hline 9 & 36 & 8 & & $X$ & & & $X$ & $X$ & $X$ \\
\hline 10 & 20 & 1 & & $x$ & & & & & \\
\hline 11 & 27 & 1 & & $X$ & & & & & \\
\hline 12 & 24 & 4 & $x$ & & & & $X$ & & $X$ \\
\hline 13 & 37 & - & & $X$ & & & & $X$ & \\
\hline 14 & 35 & 101 & $x$ & & & & $x$ & & $x$ \\
\hline 15 & 39 & 2 & $X$ & & & & $x$ & & $X$ \\
\hline 16 & 33 & 4 & & $x$ & & & $x$ & $x$ & $x$ \\
\hline 17 & 42 & 30 & $X$ & $X$ & & & $x$ & $X$ & \\
\hline 18 & 44 & 92 & $x$ & $x$ & & $x$ & $x$ & & \\
\hline 19 & 32 & 1 & & $X$ & & & $X$ & & \\
\hline 20 & 19 & 1 & & $x$ & & & $x$ & $X$ & \\
\hline
\end{tabular}

TFMV: Theft from a Motor Vehicle; TOMV: Theft of a Motor Vehicle; AVT: Aggravated Vehicle Taking; IWMV: Interference with a Motor Vehicle. 


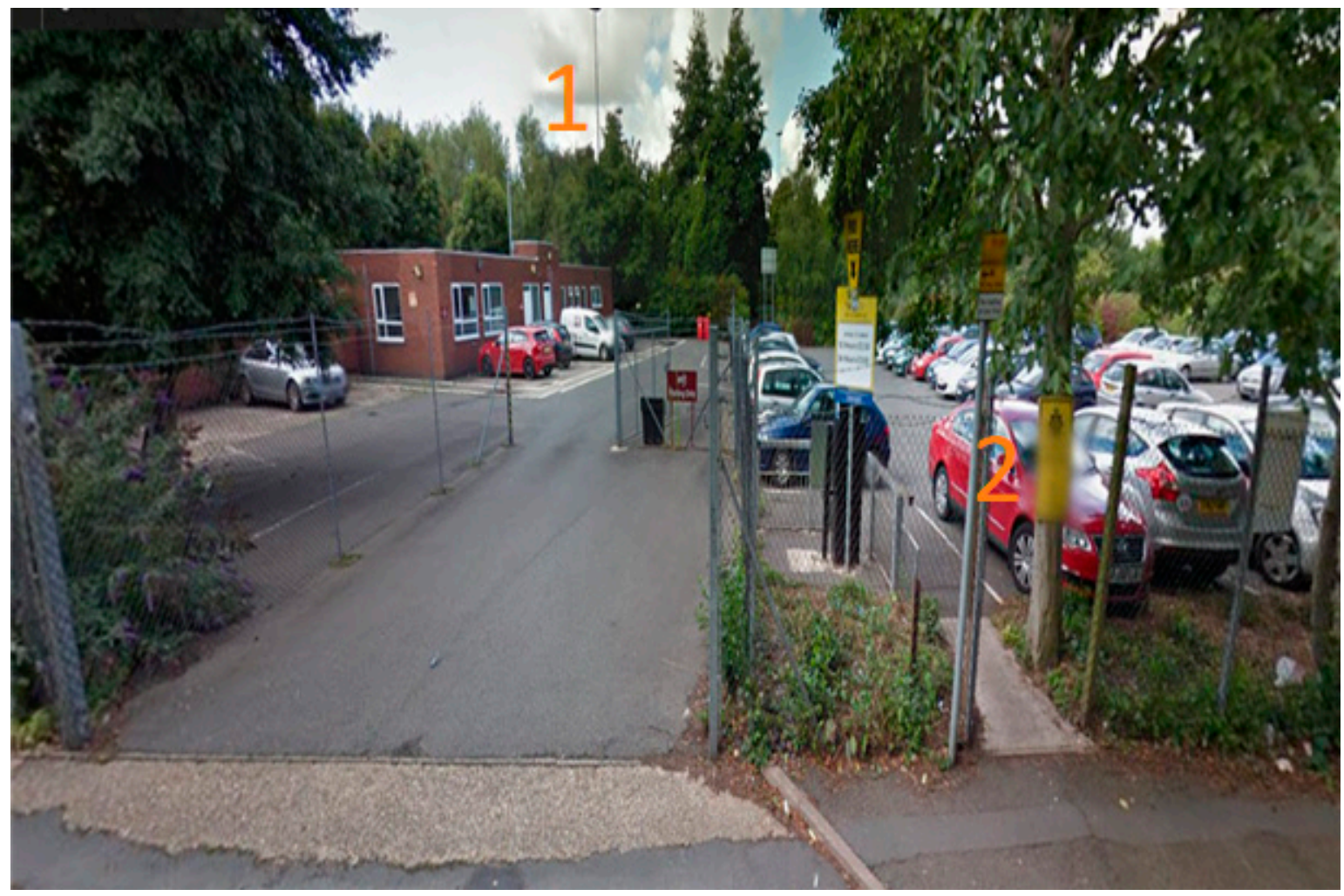

Figure A1. Location 1 (Map data (2017 Google).

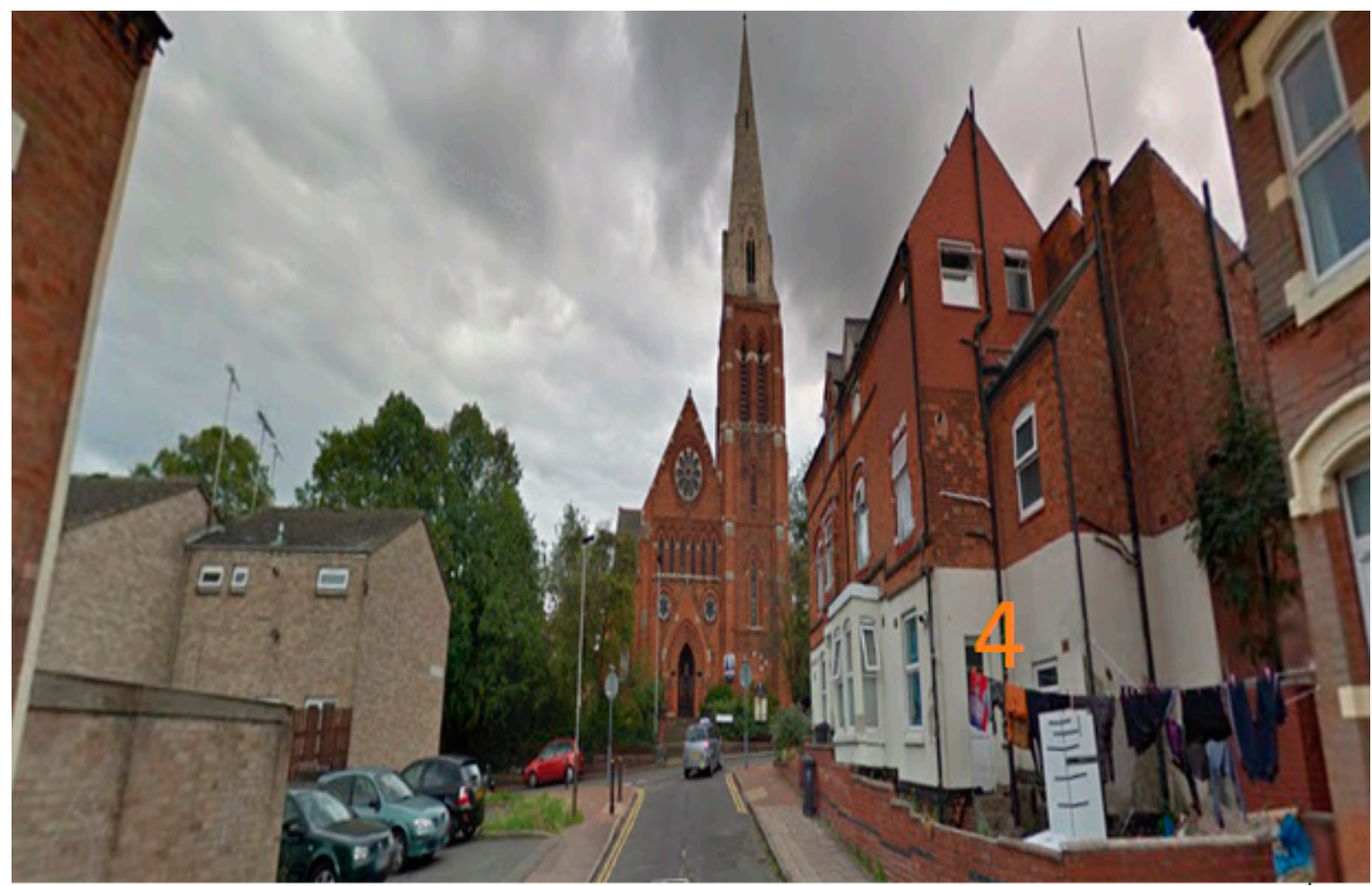

Figure A2. Location 2 (Map data (O2017 Google). 


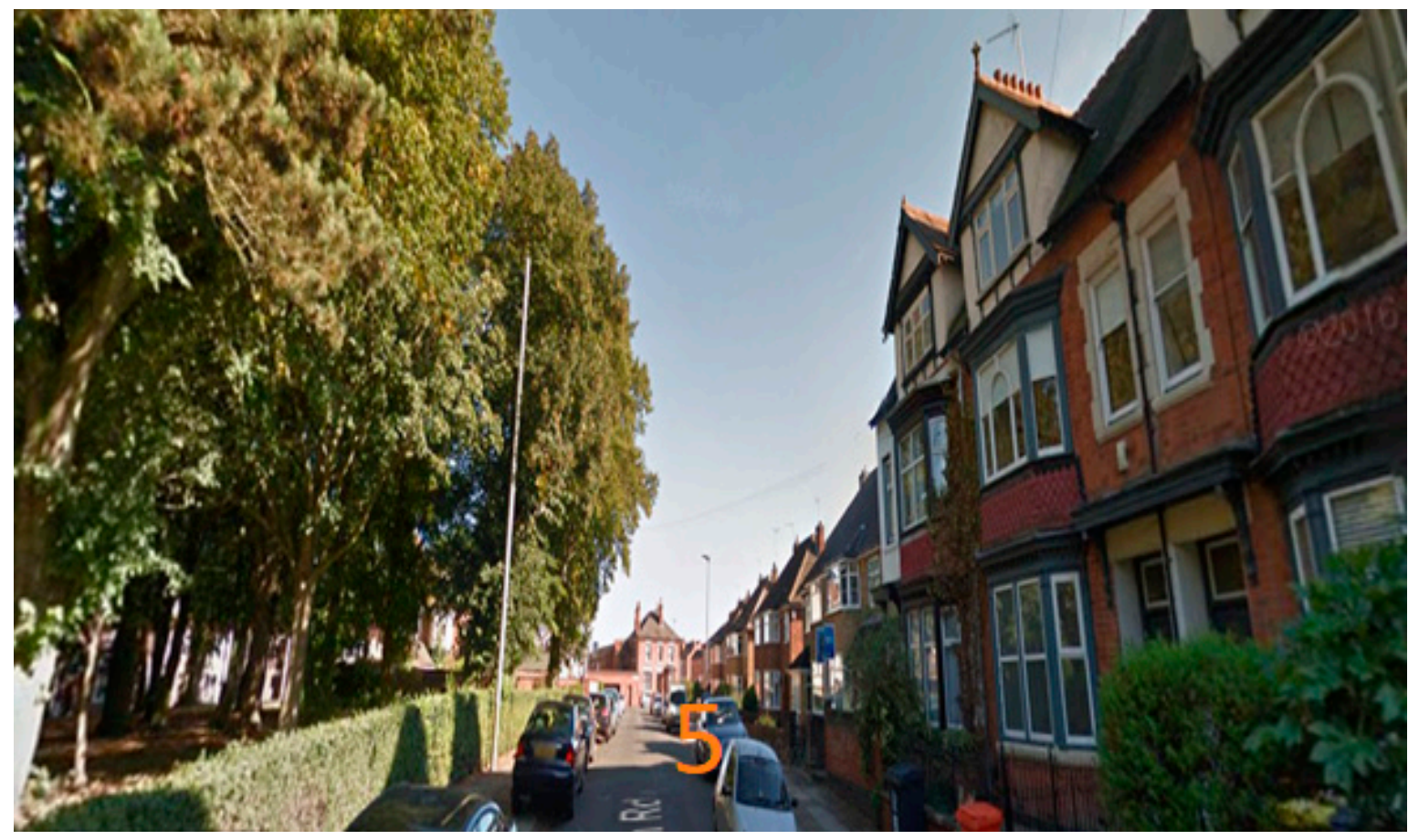

Figure A3. Location 3 (Map data @2017 Google).

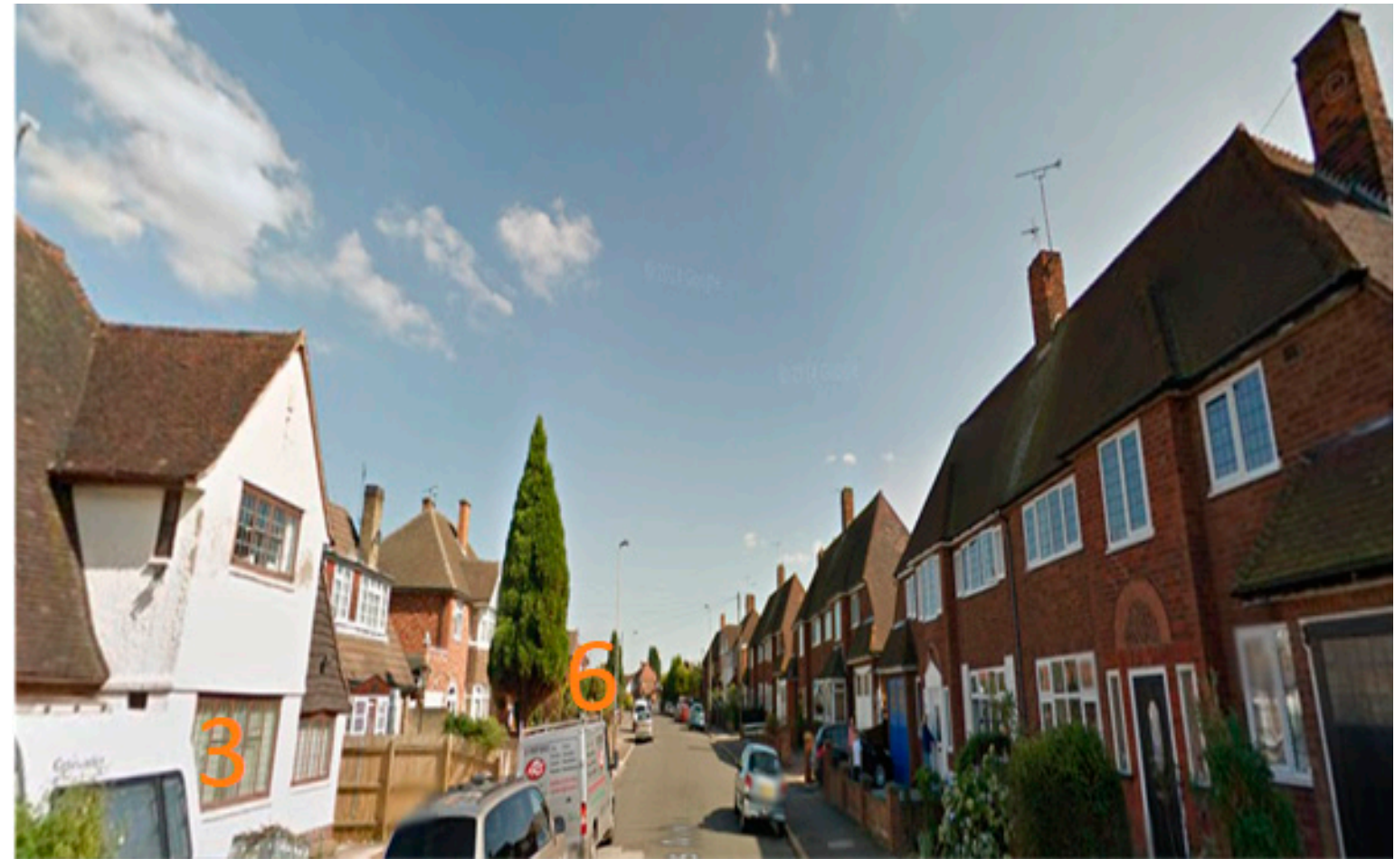

Figure A4. Location 4 (Map data @2017 Google).

\section{References}

Armitage, Rachel. 2002. To CCTV or Not to CCTV? London: Nacro.

Armitage, Rachel. 2017. Design, crime and the built environment. In Handbook of Crime Prevention and Community Safety, 2nd ed. Edited by Nick Tilley and Aiden Sidebottom. Oxon: Routledge, chp. 11. 
Armitage, Rachel. 2018. Burglars' take on crime prevention through environmental design (CPTED): Reconsidering the relevance from an offender perspective. Security Journal 31: 285-304. [CrossRef]

Armitage, Rachel, and Leanne Monchuk. 2017. What is CPTED? Reconnecting Theory with Application in the Words of Users and Abusers. In Policing: A Journal of Policy and Practice. Oxford: Oxford University Press.

Armitage, Rachel, Chris Joyce, and Leanne Monchuk. 2018. Crime Prevention through Environmental Design (CPTED) and retail crime: Exploring offender perspectives on risk and protective factors in the design and layout of retail environments. In Retail Crime: International Evidence and Prevention. Crime Prevention and Security Management. Cham: Palgrave Macmillan, chp. 6.

Bennett, Trevor, and Katy Holloway. 2010. Drug and alcohol-related crime. In Handbook on Crime. Edited by Fiona Brookman, Mike Maguire, Harriet Pierpoint and Trevor Bennett. Cullompton: Willan Publishing, chp. 29.

Bentham, Jeremy. 2012. The Works of Jeremy Bentham. Edited by John Bowring. Charleston: Nabu Press.

Bernasco, Wim. 2011. Offenders on Offending: Learning about Crime from Criminals. Oxon: Routledge.

Bowers, Kate, and Shane D. Johnson. 2003. The Role of Publicity in Crime Prevention: Findings from the Reducing Burglary Initiative; London: Home Office.

Brantingham, Paul J., and Patricia L. Brantingham. 1978. A Theoretical Model of Crime Site Selection. In Crime, Law and Sanctions. Edited by Marvin D. Krohn and Ronald L. Akers. Beverley Hills: Sage.

Brantingham, Paul J., and Patricia L. Brantingham. 1981. Environmental Criminology. Long Grove: Waveland Press.

Brown, Rick. 2016. Vehicle crime prevention and the co-evolutionary arms race: Recent offender countermoves using immobiliser bypass technology. Security Journal 30: 60-73. [CrossRef]

Bryman, Alan. 2016. Social Research Methods, 5th ed. Oxford: Oxford University Press.

Butler, Stephen, Geoffrey Baruch, Nicole Hickey, and Peter Fonagy. 2011. A Randomized Controlled Trial of Multisystemic Therapy and a Statutory Therapeutic Intervention for Young Offenders. Journal of the American Academy of Child E Adult Psychiatry 50: 1220-35.

Cherbonneau, Michael, and Heith Copes. 2006. Drive It Like You Stole It: Auto Theft and the Illusion of Normalcy. British Journal of Criminology 46: 193-211. [CrossRef]

Clarke, Ronald V. G. 1980. "Situational" Crime Prevention: Theory and Practice. British Journal of Criminology 20: 136-47. [CrossRef]

Clarke, Ronald V. 2010. Thefts of and from cars in parking facilities. In Problem-Oriented Guides for Police Problem-Specific Guides Series No. 10; Washington, DC: US Department of Justice.

Clarke, Ronald V., and Rick Brown. 2003. International Trafficking in Stolen Vehicles. Crime and Justice 30: 197-223. [CrossRef]

Clarke, Ronald Victor Gemuseus, and Marcus Felson. 2004. Routine Activity and Rational Choice. Piscataway: Transaction Publishers, vol. 5.

Collison, Mike. 1996. In Search of The High Life: Drugs, Crime, Masculinities and Consumption. British Journal of Criminology 36: 428-44. [CrossRef]

Copes, Heith. 1999. Routine Activities and Motor Vehicle Theft: A Crime Specific Approach. Journal of Crime $\mathcal{E}$ Justice Volume 22: 125-46.

Copes, Heith, and Michael Cherbonneau. 2006. The Key to Auto Theft: Emerging Methods of Auto Theft from the Offenders' Perspective. British Journal of Criminology 46: 917-34. [CrossRef]

Copes, Heith, and Lynne M. Vieraitis. 2009. Bounded rationality of identity thieves: Using offender-based research to inform policy. Criminology and Public Policy 8: 237-62. [CrossRef]

Copes, Heith, Andy Hochstetler, and Michael Cherbonneau. 2012. Getting the Upper Hand: Scripts for Managing Victim Resistance in Carjackings. Journal of Research in Crime and Delinquency 49: 249-68. [CrossRef]

Cornish, Derek B. 1994. The procedural analysis of offending and its relevance for situational prevention. In Crime Prevention Studies. Edited by Ronald V. Clarke. Monsey: Criminal Justice Press, vol. 3.

Cornish, Derek B., and Ronald V. Clarke. 1986. The Reasoning Criminal: Rational Choice Perspectives on Offending. New York: Springer.

Cornish, Derek B., and Ronald V. Clarke. 2003. Opportunities, Precipitators and Criminal Decisions: A Reply to Wortley's Critique of Situational Crime Prevention. Crime Prevention Studies 16: 41-96.

Cornish, Derek B., and Ronald V. Clarke. 2017. The rational choice perspective. In Environmental Criminology and Crime Analysis. Edited by Richard Wortley and Michael Townsley. Oxon: Routledge, chp. 2. 
CriminologyTV. 2017. 2017 AIC Occasional Seminar Martin Gill. Available online: https:/ /www.youtube.com/ watch?v=Itlo-FKGMdQ\&t=1272s (accessed on 12 November 2018).

Cromwell, Paul F., James N. Olson, and D'Aunn Wester Avary. 1991. Breaking and Entering: An Ethnographic analysis of Burglary. Newbury Park: Sage.

Curtis, Ric. 2011. Getting good data from people that do bad things: Effective methods and techniques for conducting research with hard-to-reach and hidden populations. In Offenders on Offending: Learning about Crime from Criminals. Edited by Wim Bernasco. Oxon: Routledge, chp. 9.

Ekblom, Paul. 1997. Gearing Up Against Crime: A dynamic framework to help designers keep up with the adaptive criminal in a changing world. International Journal of Risk, Security and Crime Prevention 2: 249-65.

Ekblom, Paul. 2005. The 5ls Framework: Sharing Good Practice in Crime Prevention. In Quality in Crime Prevention. Edited by Erich Marks, Anja Meyer and Ruth Linssen. Norderstedt: Books on Demand GmbH, chp. 3.

Ekblom, Paul. 2011. Deconstructing CPTED and Reconstructing it for Practice, Knowledge Management and Research. European Journal of Criminal Policy and Research 17: 7-28. [CrossRef]

Ekblom, Paul. 2017. Evolutionary Approaches to Rational Choice. In The Oxford Handbook of Offender Decision Making. Edited by Wim Bernasco, Henk Elffers and Jean-Louis Van Gelder. Oxford: Oxford University Press, chp. 3.

Elffers, Henk. 2011. Misinformation, misunderstanding and misleading as validity threats to offenders' accounts of offending. In Offenders on Offending: Learning about Crime from Criminals. Edited by Wim Bernasco. Oxon: Routledge, chp. 2.

Everson, Steve, and Ken Pease. 2001. Crime Against the Same Person and Place: Detection, Opportunity and Offender Targeting. In Crime Prevention Studies. Edited by Graham Farrell and Ken Pease. New York: Criminal Justice Press, vol. 12.

Farrell, Graham, Coretta Phillips, and Ken Pease. 1995. Like Taking Candy, Why does Repeat Victimization occur? British Journal of Criminology 35: 384-99. [CrossRef]

Felson, Marcus. 1994. Crime and Everyday Life: Insights and Implications for Society. Thousand Oaks: Pine Forge Press.

Flick, Uwe. 2006. An Introduction to Qualitative Research, 3rd ed. London: Sage Publications.

Garwood, Jeanette. 2011. A quasi-experimental investigation of self-reported offending and perception of criminal opportunity in undergraduate students. Security Journal 24: 37-51. [CrossRef]

Gill, Martin, and Janice Goldstraw-White. 2010. Theft and fraud by employees. In Handbook on Crime. Edited by Fiona Brookman, Mike Maguire, Harriet Pierpoint and Trevor Bennett. Cullompton: Willan Publishing, chp. 6.

Holloway, Katy, Trevor Bennett, and Claire Lower. 2004. Trends in Drug Use and Offending: The Results of the NEW-ADAM Programme 1999-2002; London: Home Office.

Home Office. 2016. Historical Crime Data. Available online: https://www.gov.uk/government/statistics/ historical-crime-data (accessed on 1 November 2018).

Home Office. 2018. Vehicle Offences. Available online: https://assets.publishing.service.gov.uk/government/ uploads/system/uploads/attachment_data/file/694441/count-vehicle-apr-2018.pdf (accessed on 1 November 2018).

Humphreys, Laud. 1970. Tearoom Trade. New York: De Gruyter.

Jacobs, Jane. 1993. The Death and Life of Great American Cities. New York: Random House, Inc.

Johnson, Shane D., Lucía Summers, and Ken Pease. 2006. Vehicle Crime: Communicating Spatial and Temporal Patterns. London: UCL Jill Dando Institute of Crime Science.

Johnson, Shane D., Lucía Summers, and Ken Pease. 2009. Offender as forager? A direct test of the boost account of victimization. Journal of Quantitative Criminology 25: 181-200. [CrossRef]

Kleemans, Edward, and Melvin Soudijn. 2017. Organised crime. In Handbook of Crime Prevention and Community Safety, 2nd ed. Edited by Nick Tilley and Aiden Sidebottom. Oxon: Routledge, chp. 18.

Leclerc, Benoit. 2017. Script Analysis and the SCRIPT Acronym. In Crime Prevention in the 21st Century: Insightful Approaches for Crime Prevention Initiatives. Edited by Benoit LeClerc and Ernesto U. Savona. Cham: Springer International Publishing.

Levy, Marissa P. 2014. Motor Vehicle Theft. In Encyclopaedia of Criminology and Criminal Justice. Edited by Gerben Bruinsma and David Weisburd. New York: Springer.

Light, Roy, Claire Nee, and Helen Ingham. 1993. Car Theft: The Offender's Perspective; Home Office Research Study No. 130; London: HMSO. 
Lockwood, Brian. 2012. The presence and nature of a near-repeat pattern of motor vehicle theft. Security Journal 25: 38-56. [CrossRef]

Malterud, Kirsti, Volkert Dirk Siersma, and Ann Dorrit Guassora. 2015. Sample Size in Qualitative Interview Studies: Guided by Information Power. Qualitative Health Research 26: 1753-60. [CrossRef]

Morgan, Frank. 2001. Repeat Burglary in a Perth Suburb: Indicator of Short-Term or Long-Term Risk. In Crime Prevention Studies. Edited by Graham Farrell and Ken Pease. Monsey: Criminal Justice Press, vol. 12.

National Audit Office. 2007. Using Communication to Tackle Theft from Vehicles; London: National Audit Office.

Nee, Claire. 2011. Research on residential burglary: Ways of improving validity and participants' recall when gathering data. In Offenders on Offending: Learning about Crime from Criminals. Edited by Wim Bernasco. Oxon: Routledge, chp. 13.

Nee, Claire, and Max Taylor. 2000. Examining Burglars' target selection: Interview, experiment or ethnomethodology? Psychology, Crime \& Law 6: 45-59.

Nee, Claire, and Tony Ward. 2015. Review of expertise and its general implications for correctional psychology and criminology. Aggression and Violent Behavior 20: 1-9. [CrossRef]

Nee, Claire, Martin White, Kirk Woolford, Tudor Pascu, Leon Barker, and Lucy Wainwright. 2015. New methods for examining expertise in burglars in natural and simulated environments: Preliminary findings. Psychology, Crime E Law 21: 507-13.

Newman, Oscar. 1973. Defensible Space: People and Design in the Violent City. London: Architectural Press.

Office for National Statistics. 2018. Crime in England and Wales: Year Ending June 2018. Available online: https:/ / www.ons.gov.uk/peoplepopulationandcommunity/crimeandjustice/bulletins/ crimeinenglandandwales/yearendingjune2018 (accessed on 1 November 2018).

Painter, Kate A., and David P. Farrington. 2001. The financial benefits of improved street lighting, based on crime reduction. Lighting Research and Technology 33: 3-12. [CrossRef]

Pawson, Ray. 1996. Theorizing the Interview. The British Journal of Sociology 47: 295-314. [CrossRef]

Pawson, Ray, and Nicholas Tilley. 1997. Realistic Evaluation. London: Sage.

Quinn, Anthony, and Louise Grove. 2018. 'the whole window just shatters into a million pieces and it doesn't make any sound': An examination of 'affordance' and situational cues for theft from a motor vehicle. Security Journal 31: 841-58. [CrossRef]

Ratcliffe, Jerry. 2009. Near Repeat Calculator (Version 1.3); Philadelphia: Temple University, Washington: National Institute of Justice.

Sampson, Robert J. 2006. Collective Efficacy Theory: Lessons Learned and Directions for Future Inquiry. In Taking stock: The Status of Criminological Theory. Edited by Francis T. Cullen, John Wright and Kristie Blevins. New Brunswick: Transaction Publishers, chp. 5.

Sherman, Lawrence, Peter William Neyroud, and Eleanor Neyroud. 2016. The Cambridge Crime Harm Index: Measuring Total Harm from Crime Based on Sentencing Guidelines. Policing 10: 171-83. [CrossRef]

Simon, Herbert A. 1990. Invariants of Human Behavior. Annual Review of Psychology 41: 1-20. [CrossRef]

Solon Security. 2018. Defender Signal Blocker. Available online: https:/ /www.defendersignalblocker.co.uk/ (accessed on 21 June 2018).

Suresh, Geetha, and Richard Tewksbury. 2012. Locations of Motor Vehicle Theft and Recovery. American Journal of Criminal Justice 3: 200-15. [CrossRef]

The National Crime Agency. 2011. The National Crime Agency: A Plan for The Creation of a National Crime-Fighting Capability; London: Home Office.

Welsh, Brandon C., and David P. Farrington. 2008. Effects of Closed Circuit Television on Crime. Oslo, Norway: The Campbell Collaboration, Campbell Systematic Reviews.

Wiles, Paul, and Andrew Costello. 2000. The 'Road to Nowhere': The Evidence for Travelling Criminals; London: Home Office.

Wilson, James Q., and George L. Kelling. 1982. Broken Windows: The police and neighborhood safety. The Atlantic 3: 29-38. 
Wortley, Richard. 2001. A Classification of Techniques for Controlling Situational Precipitators of Crime. Security Journal 14: 63-82. [CrossRef]

Wortley, Richard, and Michael Townsley, eds. 2017. Environmental Criminology and Crime Analysis. In Environmental Criminology and Crime Analysis, 2nd ed. Oxon: Routledge, chp. 1.

Zetinigg, Birgit, and Matthias Gaderer. 2011. Validating offenders' accounts: Learning from offender interviews with bank robbers in Austrian prisons. In Offenders on Offending: Learning about Crime from Criminals. Edited by Wim Bernasco. Oxon: Routledge, chp. 16. 